\title{
Creating Value in Manufacturing Companies
}

\author{
Iztok Palcic, Robert Ojstersek \& Borut Buchmeister
}
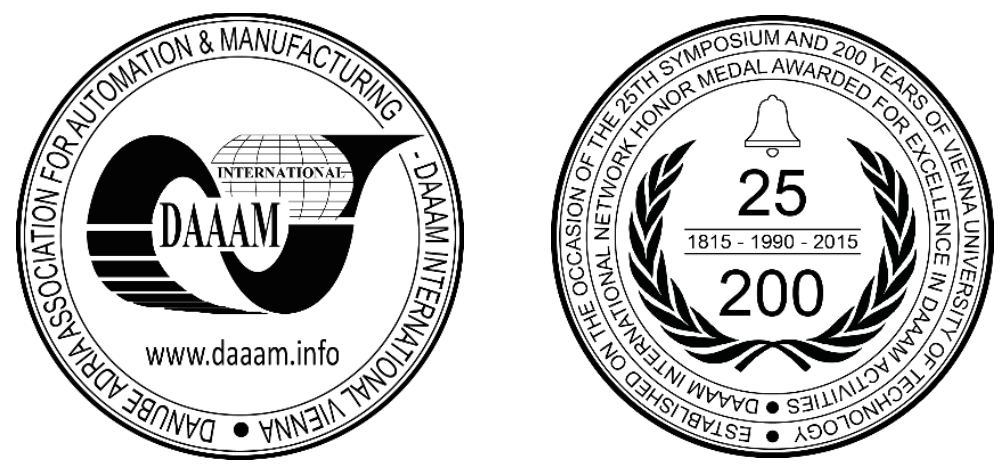

This Publication has to be referred as: Palcic, I[ztok]; Ojstersek, R[obert] \& Buchmeister, B[orut] (2018). Creating Value in Manufacturing Companies, Proceedings of the 29th DAAAM International Symposium, pp.0070-0075, B. Katalinic (Ed.), Published by DAAAM International, ISBN 978-3-902734-20-4, ISSN 1726-9679, Vienna, Austria DOI: $10.2507 / 29$ th.daaam.proceedings.010

\begin{abstract}
This paper deals with analysing value adding activities in Slovenian manufacturing companies. We are also looking into concepts of strategic and operational outsourcing. Strategic outsourcing deals with outsourcing of R\&D activities due to the lack of knowledge and skills, while operational outsourcing deals with outsourcing of parts of manufacturing and assembly activities. Our research is based on the data from the largest European manufacturing survey and it includes data from Slovenia. We have analysed manufacturing companies based on their decision to fully outsource part of their activities in terms of $\mathrm{R} \& \mathrm{D}$, manufacturing and assembly, partly outsource these activities or keep them in-house. Based on that we have studied the decisions on outsourcing $\mathrm{R} \& \mathrm{D}$, manufacturing activities in regards to different company characteristics: competitive criteria, innovation activities, company performance etc. Our results show that strategic decision on outsourcing part of companies' activities has an important impact on different companies' characteristics.
\end{abstract}

Keywords: manufacturing company; value-adding activities; strategic outsourcing; operational outsourcing; european manufacturing survey; company performance

\section{Introduction and background}

This paper focuses on the stages of value creation in Slovenian manufacturing companies. The value chain of a manufacturing company can start in the R\&D phase of new product development and is carried out through design, manufacturing, assembly, distribution and final sales activities. It is obvious that manufacturing companies do not carry out all these activities. It is also a fact that manufacturing company can carry out these activities in-house or are partially, largely or entirely outsourced to other parts of company (if existent) or to other companies / partners.

Outsourcing is commonly defined as the transfer of activities and processes previously conducted internally to an external party [1] or as turning over all or part of an organizational activity to an outside vendor [2]. The scope of outsourcing has expanded over the past two decades from focussing solely on the procurement of non-core components and services to the outsourcing of every possible activity within the value chain, such as: first, production activities at different stages of production; second, production-supporting activities including research and development, engineering, marketing, quality control, human resource management; and third, ancillary activities such as inventories management, internal and distribution logistics, plant and machinery maintenance, and data processing [3]. When deciding to outsource parts of their manufacturing operations, companies must consider the implications for their competitive priorities, such as cost, quality, flexibility, speed and innovativeness [4-5]. 
In this paper we are focusing on outsourcing of R\&D and manufacturing activities. Strategic outsourcing deals with outsourcing of R\&D activities due to the lack of knowledge and skills, while operational outsourcing deals with outsourcing of parts of manufacturing and assembly activities due to lack of capacities and the need to increase flexibility. Manufacturing flexibility relates to volume flexibilities, that is, increase production volumes in terms of increased demand or cancelation of outsourcing contracts in times of low demand. Outsourcing has a positive effect in those times of increased demand because the company does not need to invest into additional capacities. Since today it is expensive to do the entire $R \& D$ and design in house, there is a raise in outsourcing of $R \& D$ and design/engineering. At one side, keeping the R\&D in house is less risky but more expensive and may need longer times to give the final result - innovation. On the other hand outsourcing of R\&D might speed up the process and bringing new products in a more timely matter to the market [6-9].

Research shows that outsourcing produces mixed results [10]. It is also a fact that the majority of research on outsourcing is performed in developed countries [11]. Therefore, we extended research on outsourcing in manufacturing companies in less developed country. We were interested in how often our manufacturing companies include R\&D activities in their value chain. We were also interested in the extent to which manufacturing companies carry out R\&D activities and manufacturing activities by themselves and to what extent they are left - outsourced to external partners, and how these decisions affect different characteristics of companies.

\section{Research methodology}

We used data from European Manufacturing Survey (EMS) from 2015/16 round for our research. EMS is coordinated by the Fraunhofer Institute for Systems and Innovation Research - ISI, is the largest European survey of manufacturing activities. EMS questionnaire is very extensive with almost 8 pages. The survey's questions concern manufacturing strategies, the application of innovative organisational and technological concepts in production, cooperation issues, production off-shoring and backsourcing, servitisation, and questions of personnel deployment and qualification. In addition, data on performance indicators such as productivity, flexibility, quality and returns is collected. The responding firms present a cross-section of the main manufacturing industries. Included are producers of rubber and plastics, metal works, mechanical engineering, electrical engineering, textile and others. The survey was performed in manufacturing firms (NACE codes from 17 to 35) with at least 20 employees [12].

Our research is based on EMS data from Slovenian subsample from the years 2015 and 2016. We sent 739 questionnaires and received 90 answers (12,30\% response rate). We have excluded companies from textile industry, thus receiving 85 responses with a 13\% response rate. NACE divisions 22, 25 and 28 are most widely represented with around $30 \%$ of firms from NACE 25 and around 15\% for each NACE 22 and NACE 28 division. The structure of manufacturing firms based on their size, where the number of employees was the classifying criterion, has shown that the largest share of respondents is from medium sized firms (around 56\%), 25\% from small companies and 19\% from large companies.

As can be seen from Figure 1, the manufacturing companies were divided into 4 groups according to the share of inhouse contribution to value creation:

- Group 1 - large extent: companies with mostly own activities ("in-house", over $85 \%$ of activities within the company).

- Group 2 - partially outsourced: companies with a significant share of intra-corporate activities (between $25 \%$ and $85 \%$ in-house contribution).

- Group 3 - large extent outsourced: companies that mostly leave out activities to external partners ("outsourcing", only up to $25 \%$ in-house contribution).

- Group 4 - not required in the value creation process: companies that do not have or do not need activities.

Referring to the manufacturing and commercialization of your main product, which of the following stages of the value creation are done in-house per own contribution and which have been outsourced?

- If a value creation process is not necessary for your main product, please indicate it in the last row.

\section{Share of in-house \\ contribution}

to value creation

large extent

$86 \%$ - $100 \%$ in-house contribution

partially outsourced

$25 \%$ - $85 \%$ in-house contribution

large extent outsourced

$0 \%-24 \%$ in-house contribution

no required in the value

creation process
Value creation stages: $\triangleright$ Please tick per row one box only

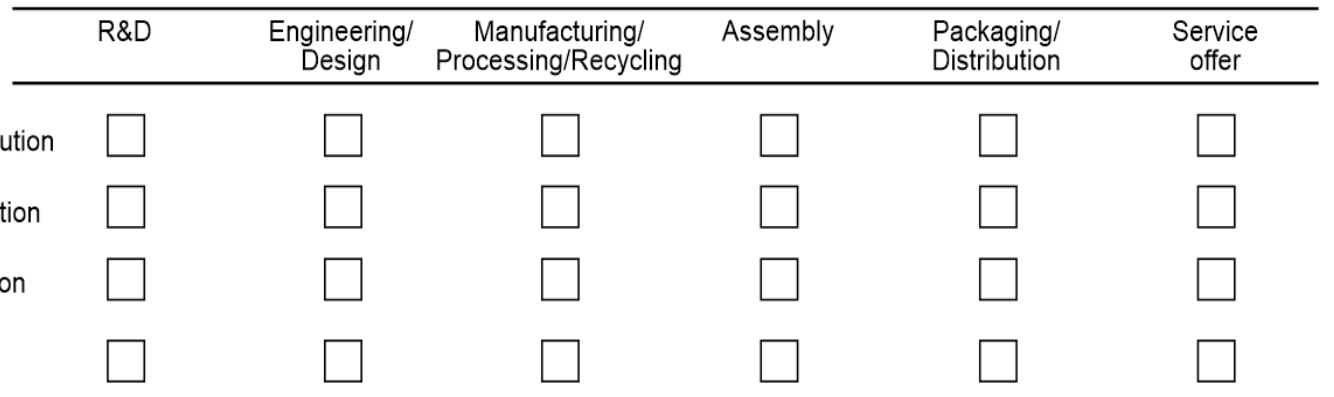

Fig. 1. Question on value creation process in manufacturing companies 
Based on this classification we formed groups of companies specifically for R\&D activities and for manufacturing activities. We also looked at the activities related to engineering/design, assembly, maintenance and service provision and packaging and distribution, but we are not dealing with them in this paper.

\section{Results and discussion}

Manufacturing companies were divided into 4 groups according to the share of in-house activities in the value-creation process with respect to R\&D activities. A large proportion of companies were present in all groups, which enabled further analysis.

- Group 1 - companies with predominantly own R\&D activities (over $85 \%$ of activities within the company).

- Group 2 - companies with a significant share of R\&D activities within the company (between $25 \%$ and $85 \%$ within the company).

- Group 3 - companies that mainly relate R\&D activities to external partners (up to $25 \%$ within the company).

- Group 4 - companies that do not have or do not need R\&D activities.

Figure 2 shows that almost $80 \%$ of manufacturing companies have R\&D activities, with over a third of manufacturing companies having a full range of R\&D activities in-house. A good 13\% of companies have a predominant share of R\&D activities in-house, and partly they carry out these activities in other parts of the company or by external partners. A good quarter of companies are those who need R\&D activities, but they are carried out mainly elsewhere. When we prepared the distribution of companies by groups for the field of engineering and design, we found that the distribution is relatively similar, with the share of manufacturing companies without engineering and design phase being only $12 \%$.

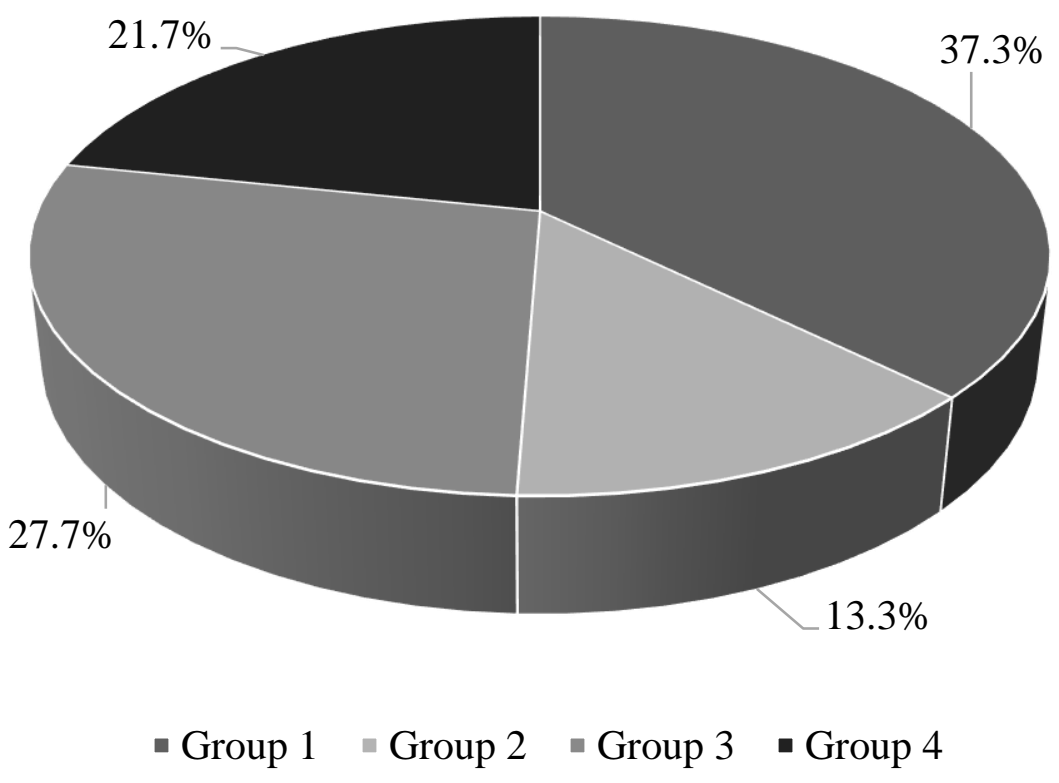

Fig. 2. Share of manufacturing companies based on outsourced R\&D activities

Manufacturing companies were divided into 2 groups according to the share of in-house activities in the value-creation process with respect to manufacturing activities. Since we are dealing with manufacturing companies, there are no representatives of group 4. Group 2 and group 3 were joined into one group.

- Group 1 - companies with predominantly own manufacturing activities (over $85 \%$ of activities within the company).

- Group 2-3 - companies with a significant share of manufacturing activities within the company (between $25 \%$ and $85 \%$ in the company) and companies with minor share of manufacturing activities within the company (up to $25 \%$ in the company).

Figure 3 shows that the share of companies with predominantly in-house manufacturing activities is very large, almost $80 \%$. Only $4 \%$ of companies had the majority of manufacturing activities in outsourcing, $18 \%$ of manufacturing companies had a significant share of manufacturing activities within the company (all together, therefore, Group 2 and Group 3 have a $21.7 \%$ share). 


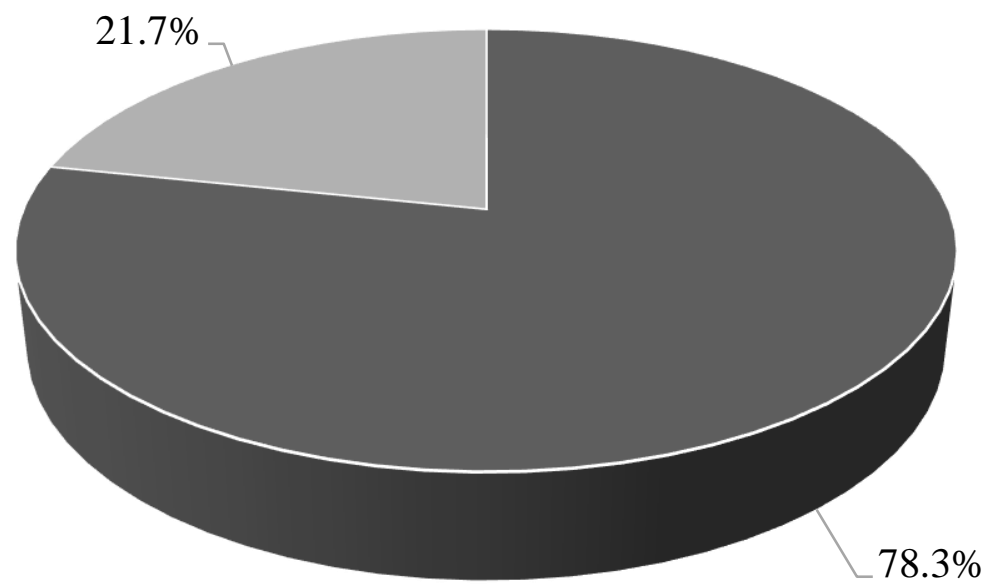

\section{- Group 1 - Group 2-3}

Fig. 3. Share of manufacturing companies based on outsourced production activities

In the survey, manufacturing companies estimated which of the six competitive criteria offered are the most important for them. They decided between the product price, the product quality, ability to develop innovative products, customisation to customers' demands, adherence to delivery times/short delivery times delivery of product-related services. Competitive criteria ranged from 1 to 6 , whereby rating 1 was the most important competitive criterion. Tables 1 and 2 show the results for both cases examined.

\begin{tabular}{|c|c|c|c|c|c|c|}
\hline $\begin{array}{c}\text { Company } \\
\text { group }\end{array}$ & Product price & $\begin{array}{c}\text { Product } \\
\text { quality }\end{array}$ & $\begin{array}{c}\text { Innovative } \\
\text { products }\end{array}$ & $\begin{array}{c}\text { Customisation } \\
\text { to customers' } \\
\text { demands }\end{array}$ & $\begin{array}{c}\text { Adherence to } \\
\text { delivery } \\
\text { times/ } \\
\text { short delivery } \\
\text { times }\end{array}$ & $\begin{array}{c}\text { Product- } \\
\text { related } \\
\text { services }\end{array}$ \\
\hline Group 1 & $\mathbf{3 , 8 5}$ & $\mathbf{2 , 3 7}$ & $\mathbf{3 , 7 0}$ & $\mathbf{2 , 6 3}$ & $\mathbf{3 , 3 7}$ & $\mathbf{5 , 0 7}$ \\
\hline Group 2 & $\mathbf{3 , 6 7}$ & $\mathbf{2 , 1 1}$ & $\mathbf{4 , 1 1}$ & $\mathbf{3 , 2 2}$ & $\mathbf{3 , 4 4}$ & $\mathbf{4 , 4 4}$ \\
\hline Group 3 & $\mathbf{2 , 6 7}$ & $\mathbf{2 , 3 8}$ & $\mathbf{5 , 1 4}$ & $\mathbf{2 , 6 2}$ & $\mathbf{3 , 1 0}$ & $\mathbf{5 , 1 0}$ \\
\hline Group 4 & $\mathbf{3 , 9 3}$ & $\mathbf{2 , 2 9}$ & $\mathbf{5 , 0 0}$ & $\mathbf{2 , 2 1}$ & $\mathbf{2 , 9 3}$ & $\mathbf{4 , 6 4}$ \\
\hline
\end{tabular}

Table 1. Share of in-house R\&D activities and importance of competitive criteria

Table 1 shows that for manufacturing companies, in general, the most important competitive criterion is the product quality, and secondly, it is customisation to the customer's demands. The product price is just in fourth place. It can be noted that for companies that do not have R\&D activities the customisation to the customer's demands is practically as important a competitive criterion as the product quality. We can also conclude that the competitive criterion development of innovative products in companies with less or no $R \& D$ activities is an increasingly less important competitive criterion than in other groups.

\begin{tabular}{|c|c|c|c|c|c|c|}
\hline $\begin{array}{c}\text { Company } \\
\text { group }\end{array}$ & Product price & $\begin{array}{c}\text { Product } \\
\text { quality }\end{array}$ & $\begin{array}{c}\text { Innovative } \\
\text { products }\end{array}$ & $\begin{array}{c}\text { Customisation } \\
\text { to customers' } \\
\text { demands }\end{array}$ & $\begin{array}{c}\text { Adherence to } \\
\text { delivery } \\
\text { times/ } \\
\text { short delivery } \\
\text { times }\end{array}$ & $\begin{array}{c}\text { Product- } \\
\text { related } \\
\text { services }\end{array}$ \\
\hline Group 1 & $\mathbf{3 , 4 7}$ & $\mathbf{2 , 1 4}$ & $\mathbf{4 , 4 2}$ & $\mathbf{2 , 7 0}$ & $\mathbf{3 , 3 5}$ & $\mathbf{4 , 9 1}$ \\
\hline Group 2-3 & $\mathbf{3 , 5 7}$ & $\mathbf{3 , 0 7}$ & $\mathbf{4 , 5 0}$ & $\mathbf{2 , 2 9}$ & $\mathbf{2 , 6 4}$ & $\mathbf{4 , 9 3}$ \\
\hline
\end{tabular}

Table 2. Share of in-house production activities and importance of competitive criteria

Table 2 offers results that are even more interesting. We can see that for manufacturing companies, which have production mostly in-house, the most important competitive criterion is the product quality, while for other manufacturing companies, the customisation to the customer's demands is the most important competitive criterion. 
Adherence to delivery times/short delivery times is also more important competitive criterion than product quality. Obviously, the fact that you do not have a real control over production affects the ability to ensure product quality. We also asked manufacturing companies to evaluate which innovation areas are most important for their company. Companies selected between the development and delivery of product-related services, the introduction of new organizational concepts, the introduction of technical innovations in the production process and the development of new products. The innovation areas ranged from 1 to 4 , with grade 1 the most important area. Tables 3 and 4 show the results for both cases examined.

\begin{tabular}{|c|c|c|c|c|}
\hline Company group & $\begin{array}{c}\text { Complementing } \\
\text { product offers with } \\
\text { services }\end{array}$ & $\begin{array}{c}\text { New organizational } \\
\text { concepts }\end{array}$ & $\begin{array}{c}\text { New technical } \\
\text { production processes }\end{array}$ & New products \\
\hline Group 1 & 2,97 & 3,59 & 2,07 & 1,38 \\
\hline Group 2 & 2,67 & 2,89 & 2,67 & 1,78 \\
\hline Group 3 & 2,84 & 2,81 & 1,77 & 2,58 \\
\hline Group 4 & 2,79 & 3,14 & 1,64 & 2,43 \\
\hline
\end{tabular}

Table 3. Share of in-house R\&D activities and importance of innovation areas

Table 3 indicates that for companies with R\&D activities entirely or predominantly in-house, the most important innovation areas is related to the development of new products. In Group 3 and 4, the most important area is the introduction of various technical innovations in the manufacturing company. If we look at Table 4, then the rank of relevance changes, as technical innovations in the production process are the most important area in companies that have production entirely or mainly in-house.

\begin{tabular}{|c|c|c|c|c|}
\hline Company group & $\begin{array}{c}\text { Complementing } \\
\text { product offers with } \\
\text { services }\end{array}$ & $\begin{array}{c}\text { New organizational } \\
\text { concepts }\end{array}$ & $\begin{array}{c}\text { New technical } \\
\text { production processes }\end{array}$ & New products \\
\hline Group 1 & 2,93 & 3,21 & 1,82 & 2,04 \\
\hline Group 2-3 & 2,53 & 3,13 & 2,20 & 2,13 \\
\hline
\end{tabular}

Table 4. Share of in-house production activities and importance of innovation areas

Next we will show the relationship between the share of in-house activities in the process of value creation and some specific characteristics of companies (Table 5 and Table 6).

\begin{tabular}{|c|c|c|c|c|c|}
\hline $\begin{array}{c}\text { Company } \\
\text { group }\end{array}$ & $\begin{array}{c}\text { Share of graduates } \\
\text { in the company } \\
{[\%]}\end{array}$ & $\begin{array}{c}\text { Share of } \\
\text { employees in } \\
\text { R\&D sector [\%] }\end{array}$ & $\begin{array}{c}\text { Introduction of } \\
\text { new products to } \\
\text { market in last 3 } \\
\text { years [\%] }\end{array}$ & $\begin{array}{c}\text { Share of } \\
\text { companies that } \\
\text { produced products } \\
\text { older than 10 } \\
\text { years [\%] }\end{array}$ & $\begin{array}{c}\text { Expenditures on } \\
\text { R\&D as share of } \\
\text { turnover [\%] }\end{array}$ \\
\hline Group 1 & 21,97 & 13,38 & 84 & 100 & 4,7 \\
\hline Group 2 & 17,20 & 10,56 & 55 & 82 & 2,6 \\
\hline Group 3 & 16,64 & 5,28 & 35 & 78 & 2,7 \\
\hline Group 4 & 13,38 & 1,38 & 44 & 100 & 0,3 \\
\hline
\end{tabular}

Table 5. Share of in-house R\&D activities and selected manufacturing companies characteristics

\begin{tabular}{|c|c|c|c|c|c|}
\hline $\begin{array}{c}\text { Company } \\
\text { group }\end{array}$ & $\begin{array}{c}\text { Share of graduates } \\
\text { in the company } \\
{[\%]}\end{array}$ & $\begin{array}{c}\text { Share of } \\
\text { employees in } \\
\text { R\&D sector [\%] }\end{array}$ & $\begin{array}{c}\text { Introduction of } \\
\text { new products to } \\
\text { market in last 3 } \\
\text { years [\%] }\end{array}$ & $\begin{array}{c}\text { Share of } \\
\text { companies that } \\
\text { produced products } \\
\text { older than 10 } \\
\text { years [\%] }\end{array}$ & $\begin{array}{c}\text { Expenditures on } \\
\text { R\&D as share of } \\
\text { turnover [\%] }\end{array}$ \\
\hline Group 1 & 16,49 & 5,05 & 58 & 91 & 3,0 \\
\hline Group 2-3 & 21,88 & 7,12 & 50 & 94 & 2,5 \\
\hline
\end{tabular}

Table 6. Share of in-house production activities and selected manufacturing companies characteristics

The first characteristic we observed is the share of employees in a manufacturing company with a high level of education. In Table 5, we see a clear link between the share of in-house R\&D activities and the share of employees with a high level of education. Less in-house R\&D activities also means a lower share of highly educated staff. 
Something similar can also be seen in Table 6, where the share of employees with a higher education is higher in companies, where there are several manufacturing activities in outsourcing. This reflects the fact that these manufacturing companies stick to more in-house R\&D activities. A very similar picture is related to the question of the number of staff employed in the R\&D sector in the company and the amount of annual revenues invested by the company in $R \& D$ activities. We explain the answers to these questions in the same way as the answer to the share of highly educated staff.

The ability of companies to introduce new products to the market was determined by asking companies whether they introduced a new product in the period from 2012 to 2015 . Table 5 clearly indicates that the share of companies that have introduced a new product on the market over a period of three years is higher in the group of companies with higher share of in-house $R \& D$ activities. The share of in-house manufacturing activities does not have a major impact on the ability to introduce new products to the market. We also asked companies whether they still produce products that they have been in the production program for 10 years or more. We got a somewhat surprising result in Table 5, where manufacturing companies, with predominantly in-house R\&D activities, still manufacture products, that have been a part of production program for more than 10 years. Generally, more than $80 \%$ of Slovenian manufacturing companies still manufacture products that are 10 or more years as a part of companies' production program. This number is not higher than, for example, in Austria or Germany.

\section{Conclusion}

The results of our research have shown some interesting and important links between the decisions of the company, to what extent keep R\&D activities and manufacturing activities in-house, as well as the selected characteristics of companies. The product quality today is clearly the main competitive criterion of the company regardless of the share of R\&D activities that the companies carry out. In any case, the fact is that half of the manufacturing companies have a major share of R\&D activities in-house. For these companies, innovation in product development and the ability to develop new products is crucial. Such companies also have a higher share of highly educated staff and invest a greater share of their revenues in R\&D activities. For companies that are primarily focused on manufacturing activities, investment in technical innovations in the production process is very important.

\section{Acknowledgments}

The authors acknowledge the financial support from the Slovenian Research Agency (research core funding No. P20190).

\section{References}

[1] Ellram, L. \& Billington, C. (2001). Purchasing leverage considerations in the outsourcing decision, European Journal of Purchasing \& Supply Management, Vol. 7, No. 1, pp. 15-27

[2] Barthelemy, J. (2003). The seven deadly sins of outsourcing, Academy of Management Executive, Vol. 17, No. 2, pp. 87-100

[3] Gottfredson, M., Puryear, R. \& Phillips, S. (2005). Strategic sourcing: from periphery to the core, Harvard Business Review, Vol. 83, No. 2, pp. 132-139

[4] Gray, J. V., Roth, A. V. \& Tomlin, B. (2009). The influence of cost and quality priorities on the propensity to outsource production, Decision Sciences, Vol. 40, No. 4, pp. 697-726

[5] Hätonen, J. \& Eriksson, T. (2009). 30 years of research and practice of outsourcing - exploring the past and anticipating the future, Journal of International Management, Vol. 15, No. 2, pp. 142-55

[6] Scherrer-Rathje M., Deflorin, P. \& Anand, G. (2014). Manufacturing flexibility through outsourcing: effects of contingencies, International Journal of Operations \& Production Management, Vol. 34, No. 9, pp. 1210-1242

[7] Prester, J. \& Palčič, I. (2017). Outsourcing of R\&D versus operational outsourcing and its effects on flexibility and time to market, Euroma2017, 24th EurOMA conference, 01/05 July 2017, Edinburgh, Scotland, pp. 1-10

[8] Todic V., Cosic I., Maksimovic R., Tasic N. \& Radakovic N. (2017). Model for Simulation of Life Cycle Costs at the Stage of Product Development, International Journal of Simulation Modelling, Vol. 16, No. 1, pp. 108-120

[9] Zhao J. Y., Wang Y. J., Xi X. \& Wu G. D. (2017). Simulation of Steel Production Logistics System Based on MultiAgents, International Journal of Simulation Modelling, Vol. 16, No. 1, pp. 167-175

[10] Verwaal, E. (2017). Global outsourcing, explorative innovation and firm financial performance: A knowledgeexchange based perspective, Journal of World Business, Vol. 52, No. 1, pp. 17-27

[11] Größler, A., Laugen, B. T., Arkader, R. \& Fleury, A. (2013). Differences in outsourcing strategies between firms in emerging and in developed markets, International Journal of Operations \& Production Management, Vol. 33, No. 3, pp. 296-321

[12] Palčič, I. \& Buchmeister, B. (2016). Energy and material saving technologies in Slovenian manufacturing firms, Annals 2016, 27th International DAAAM Symposium "Intelligent Manufacturing \& Automation", 23/30 206, October 2016, Mostar, Croatia, Katalinic, B. (Ed.), pp. 1-6, DAAAM International Vienna, Austria 